\title{
Self-Identification of Victimization of Labor Trafficking
}

\author{
Masja van Meeteren and Jing Hiah
}

\section{Contents}

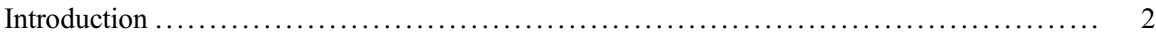

Explaining Low Self-Identification of Victimization of Labor Exploitation .............. 4

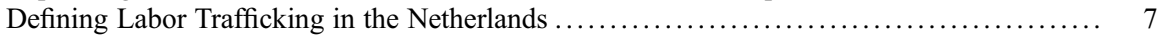

Two Trajectories to Self-Identification in the Netherlands $\ldots \ldots \ldots \ldots \ldots \ldots \ldots \ldots \ldots \ldots \ldots, \quad 7$

Discussion ............................................................. 9

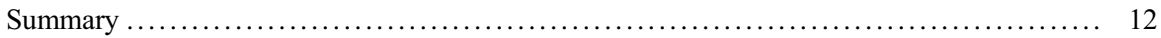

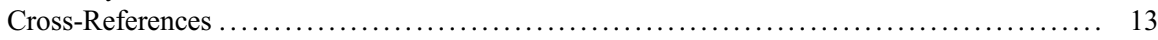

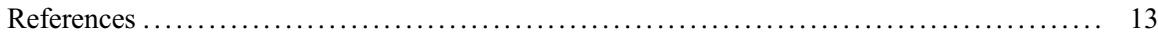

\begin{abstract}
Although labor exploitation has been criminalized as human trafficking, also known as labor trafficking, forced labor, or modern slavery, globally, many cases remain undetected. In part, this underreporting is arguably due to low levels of self-identification of victimization of labor trafficking. Low self-identification suggests that a discrepancy exists between legal definitions of labor trafficking victimhood and the lived experiences of work and employment by what are often labor migrants. This contribution discusses scholarly literature that identifies factors that obstruct self-identification among those subjected to labor exploitation. Also, a study is discussed that analyzed how some victims do arrive at selfidentification. This contribution finds that labor trafficking often refers to situations in which migrants have consciously left their country of origin in search of
\end{abstract}

M. van Meeteren $(\bowtie)$

Department of Criminology, Leiden University, Leiden, The Netherlands

e-mail: m.j.van.meeteren@law.leidenuniv.nl

J. Hiah

Department of Interdisciplinary Social Science, Utrecht University, Utrecht, The Netherlands e-mail: j.w.hiah@uu.nl 
work. Their work conditions may be valued as a temporary arrangement to achieve upward social mobility and considered from their home country's work and income standards. Therefore, such migrants may perceive themselves as active agents of their destiny who make their own decisions in engaging in certain working conditions and not as passive victims of exploitation. Finally, two trajectories through which victims of labor exploitation do arrive at self-identification are discussed. On the first path, the victim gradually comes to selfidentification. On the second path, a radical event in the personal life of victims triggers them to become aware of their victimhood. The insights provided in this chapter are valuable for the future combat of labor trafficking, in which victim self-identification plays an important role.

\section{Keywords}

Labor exploitation · Labor trafficking $\cdot$ Victimology $\cdot$ Self-identification $\cdot$ Labor migration $\cdot$ Victim identification

\section{Introduction}

In many European countries, legislation on human trafficking for labor exploitation mostly follows the terms of the Palermo protocol and the EU framework decision on trafficking in human beings. Labor exploitation criminalized as human trafficking labor trafficking - is considered a severe violation of human rights, and as interfering with free market principles of fair competition (Jägers and Rijken 2014). Unlike sex trafficking, labor trafficking includes all types of forced labor that do not have a sexual component. Whereas labor trafficking once lagged far behind sex trafficking, concerning global attention, since its insertion to the Palermo protocol, its profile is now increasing as a significant social problem. As labor trafficking features high on national and international policy agendas, resources are increasingly devoted to its combat (Goodey 2008: 434).

Despite the increased policy attention, there is still relatively little research on labor trafficking (Cockbain et al. 2018; Joarder and Miller 2014). In addition, existing research in the field of human trafficking often concerns general overviews or critiques of the literature, or legal studies focusing on the question of how to define human trafficking. "Only a few researchers have conducted carefully designed empirical studies in this field" (Cockbain et al. 2018; Weitzer 2014: 8). Furthermore, by far the largest bulk of research has focused on sexual exploitation, leaving labor trafficking sidelined (Weitzer 2014: 7). As a result, our understanding of the lived experiences of victims of human trafficking is largely confined to experiences of sexual exploitation (Kaye et al. 2014).

The limited understanding of how labor trafficking is experienced is obviously problematic in itself but even more so considering the presumed scale of the crime. The International Labour Organization (ILO) estimates that worldwide, at any given time in 2016, 40.3 million people are in a situation of modern slavery, including 24.9 million in forced labor (including sexual exploitation). Scholars assert 
that there is no solid evidence basis to claim that labor trafficking outnumbers sex trafficking, but "it is certainly plausible that the international market for all types of cheap labor combined (in agriculture, manufacturing, mining, domestic service, etc.) eclipses the market for sexual services and therefore that trafficking or forced labor would be more prevalent outside the commercial sex sector" (Weitzer 2014: 13; Kaye et al. 2014). Some scholars in fact argue that "human trafficking needs to be reframed as a labour migration issue" (e.g., Bélanger 2014: 88).

Despite the increased global attention, many victims of human trafficking are undetected, and this is perhaps even more so for victims of labor trafficking (Van der Leun and Van Schijndel 2012, 2016). Although identification procedures are leading to an increase in the recognition of victims, the actual number of victims is estimated to be much higher (Zhang 2012; Goodey 2008). A recent estimation using multiple systems estimation (MSE) performed by UNODC and the Dutch National Rapporteur indicates that estimated numbers are four to five times higher than the recorded numbers of detected victims in the Netherlands (UNODC and Dutch National Rapporteur 2017).

That many victims of labor trafficking remain undetected is partly because both the general public and professionals believe that labor trafficking is less severe than sex trafficking (Barrick et al. 2014). However, the available empirical research, though limited, demonstrates severe consequences for victims of labor trafficking. Some are misled about their working conditions, locked in enclosed premises, and subjected to physical violence (Weitzer 2014). Moreover, victims can experience psychological and physical problems similar to those facing victims of sexual exploitation (Turner-Moss et al. 2014). The idea that victimization of labor trafficking is not as damaging is further strengthened, and it is argued here, by a low selfidentification of victimhood among those that would legally qualify as victims of labor trafficking. Moreover, the degree of self-identification is low across the entire spectrum of exploitative situations, even for those who have experienced extreme forms of violence, fraud, and compulsion (Petrunov 2014).

Self-identification of victimhood is essential to the combat of labor trafficking for three main reasons. First, if persons do not consider themselves as victims - in many cases even after they have been made aware that they do qualify as victims - it is difficult to create the support structures needed to help them. Second, in the prosecution of labor trafficking, alleged victims can play a crucial role by taking the witness stand. If potential victims fail to self-identify, they are less willing to cooperate in criminal investigations. Third, the lack of self-identification raises important questions regarding the suitability of the legal framework and whether it is adequately attuned to the lived experiences of those involved. For these three reasons, to effectively combat labor trafficking in the future, it is necessary to develop a better understanding of the social and cultural processes concerning self-identification of victimization of labor trafficking.

In this contribution, two questions are explored: (1) Why there is such a low selfidentification of victimhood of labor trafficking; and (2) given the obstacles identified, how do some victims ultimately come to self-identify as victims? The first question is answered by discussing international scholarly literature in which 
obstructions to self-identification are identified. Insights are also included from the literature on sexual exploitation as it involves a framework that harnesses a rich tradition of debating dominant victimization discourses, which benefits our understanding of self-identification of victimization in labor exploitation. The second question is answered by discussing the results of an academic study undertaken in the Netherlands (and published in Dutch), in which one of the authors was involved (see Tielbaard et al. 2016; Van Meeteren 2016). At the time of writing, this appeared to be the only study available that has explicitly analyzed how victims of labor trafficking arrived at self-identification with their victimhood (see, also, Cockbain et al. 2018).

\section{Explaining Low Self-Identification of Victimization of Labor Exploitation}

Self-identification of victimization is not only low among victims of labor trafficking. From the broader victimological literature, it appears that victim self-identification can also be low among other types of crime. This literature explains low rates of self-identification as a consequence of victims' narrow definitions of victimization or because of psychological mechanisms such as denial or repression (Best 1999). An implicit assumption in such studies is that even though victims do not recognize their victimization, they should nonetheless be considered victims because they can be considered victims from a legal point of view. This legal perspective on victimhood is also visible in most of the literature that addresses the obstacles to self-identification of victimhood of human trafficking and labor exploitation. Problematic about comparing victimhood of labor trafficking is that those who engage in practices that legally could be considered a case of labor trafficking often consent to work in these circumstances. These different questions concerning victimhood and self-identification of victimization are related to what critical victimologists would describe as the politics of victimhood (e.g., Jacoby 2015): who is recognized as a victim is a contested issue and is telling of the different power relations between groups in society. For instance, in the case of trafficking victims, we focus on the role of the state in protecting victims and punishing offenders, but instead, we could question the state's role in devising policies that lead to labor market vulnerabilities and exploitation of specific populations such as irregular labor migrants in the first place (Irregular migrant workers refer here to immigrants who are undocumented and carry out work "under the radar" in terms of employment rights and pay grade).

A first common explanation in the literature for low self-identification is that victims often have no knowledge of their rights, which makes it difficult for them to determine whether they are victims of labor trafficking (Dutch National Rapporteur 2009). Consequently, employees may claim that they are victims of labor trafficking only after being informed about their labor rights (Postma and Wijk 2012). Lack of knowledge about one's rights is often exacerbated by their social position, which makes it difficult to improve their access to information about their labor rights. Low-skilled labor migrants, for example, often do not speak the native language, 
have a limited social network mostly comprised of other labor migrants, and have little understanding of their rights. This explanation for the low self-identification of victims is the most hopeful one regarding offering possibilities to overcome barriers. It implies that if victims are better informed, they do come to recognize and identify with their victimhood. Self-identification might hence be improved by "enlightening" victims about their rights. Although this may seem promising as a problemsolving strategy, so far, sound empirical evidence that supports this line of thinking is unfortunately still lacking (Cockbain et al. 2018).

Second, migration background and the mindset that accompanies a migratory project may otherwise be a barrier to self-identification. People may accept exploitation, as a means to an end, or the desired outcome back in their country of origin (van Meeteren 2014). Alternatively, as the research by Bloch and McKay (2013) shows, migrants may perceive the (from a legal point of view) exploitative labor conditions as a necessary step in their upward labor market mobility. In other words, they see it as something that is inextricably intertwined with migration. It is something they knowingly accept as being part of the deal. Research by Barrick et al. (2014), for example, shows that "irregular migrant" workers often see exploitative circumstances as usual for illegal workers, and that is identified as a victim of trafficking does not always benefit migrants in realizing their migration plans. Moreover, labor conditions deemed as exploitative by outsiders may still be attractive to migrants as they offer possibilities to learn and receive training on specific skills that will contribute to their upward labor market mobility (e.g., Bloch and McKay 2013).

In addition, Parreñas (2011) study on Filipino female labor migrants in Japan convincingly demonstrates how the criminalization of Filipino hostess work as trafficking in Japan has resulted in the eradication of this work, thereby preventing migrant Filipino women from choosing one of the few pathways toward "economic mobility from their life of abject poverty" (Parreñas 2011: 335). Despite being employed in indentured labor, the Filipina hostesses had considerable agency in entering these relations, and many did not want to leave these arrangements. Moreover, even if they wanted to quit their jobs as hostesses, they could not do so without facing criminalization as undocumented workers. This paradoxical position is coined by Parreñas as indentured mobility and presents a nuanced view that acknowledges actors' vulnerability to human rights violations but "simultaneously rejects the prevailing discourse on human trafficking that paints [labor migrants] as helpless victims in need of "rescue" (Marmo and Chazal 2016; Parreñas 2011). Overall, these examples demonstrate that even though some migrants may be aware of their rights, they see and accept exploitative circumstances to be a regular component of migration processes. As such, they do not see themselves as victims but as active agents of their migration projects that include exploitation. These insights question whether a situation should be considered exploitation at all if the directly involved do not consider themselves to be exploited.

A third set of explanations for the lack of self-identification tend to emphasize that exploitation takes place within the setting of a relationship that involves power relationships governed by a "moral economy" that legitimizes those imbalances 
based on ethnic, hierarchical, religious, or political differences or the basis of perceived vulnerabilities (Datta and Bales 2013). These explanations react on dominant representations of human trafficking that suggest that workers/victims depend on employers/perpetrators in a one-way street, in which the workers/victims are deprived of any agency and in which the traffickers have a hegemonic power position. However, these explanations emphasize that this not be always the case. Although power imbalances are likely to exist between both parties, explanations that emphasize the relational aspect of trafficking situations also acknowledge that relationships involve different interdependencies. Analyzing Dutch legal case files on labor trafficking, Postma and Wijk (2012) write that in some "moral economies," both the employer and the employee accept a hierarchical relationship that is much stronger than is generally accepted in the Netherlands.

This perspective is underlined by Staring (2012) and, later, Hiah and Staring $(2013,2016)$ in their respective research among young undocumented migrants and the Chinese catering industry that explain how people who could be regarded as victims of labor exploitation in the Netherlands do not see themselves as victims. Moreover, when they do identify with victimhood, they tend to see themselves as victims of migration policies or of not getting a work permit from the government. They do not typically identify with victimhood of human trafficking. Only in the exceptional circumstances in which informal labor standards are grossly exceeded do they feel severely disadvantaged. This implies that although some workers may recognize their labor circumstances as unlawful, they accept them because they are legitimized in the "moral economy" that governs their work. In other words, although they may recognize their position to be unlawful, they do not identify with the victimhood position that accompanies it or the idea that they are exploited. The normative framework used to interpret their situation is different from the normative framework that is used by institutions that are setup to help victims and prosecute the perpetrators.

Whereas the first set of obstructions to self-identification can be used as inspiration to develop interventions and policies, this is much more difficult to achieve for the second and third set of reasons. These raise questions concerning the appropriateness of related legal frameworks and their lack of correspondence with the lived experiences of those involved. A discrepancy exists, therefore, between perceptions of legal victimhood by enforcement agencies and support institutions and the perception of the situation that "victims" themselves have. This raises the question of whether a legal view does justice to the social reality in which it attempts to intervene. Scholars that adopt a social constructivist perspective on reality argue that a strictly legal perspective undervalues the lived experiences of actors and perhaps even, despite best intentions, patronizes the actors involved. Such scholars argue that trafficking should not be regarded as only something that happens to a person but as something that is experienced by a person (e.g., Yea 2012; Vijeyarasa 2012).

Reviewing this literature, it can be argued that labor trafficking should not be considered as one end of the binary between free labor, where employment arrangements are chosen out of free will, and, on the other hand, labor trafficking, where someone is deprived of any agency and had no choice on whether to work in a 
particular situation. Instead, labor trafficking is best considered in the context of employment as a dynamic process, in which in-between positions exist between free work and unfree work. To capture this dynamic character, various authors have highlighted the different in-between positions between the two binary opposites. For instance, Skrivankova (2010) conceptualized trafficking within the "continuum of exploitation," while Yea (2012) refers to "shades of gray." These concepts move away from a binary conception of trafficking and capture the complex situational combinations that exist between decent work and forced labor and an individual's work situation as it evolves (e.g., Strauss and McGrath 2017). Whereas it is often already difficult to legally establish social phenomena that constitute human trafficking, it should further be evident that for any person in an exploitative situation, their situation can be interpreted in multiple ways. In short, a strictly legal point of view does not do justice to the way that victims perceive their situation. At the same time, however, a complete relativist perspective risks labeling situations that are exploitative as noncriminal because they are not experienced as such by its victims.

\section{Defining Labor Trafficking in the Netherlands}

In the Netherlands, labor exploitation is criminalized as trafficking in human beings in Article 273f of the Dutch Criminal Code ( $\mathrm{Sr}$ ). Legal practice has shown that it is difficult to precisely determine labor exploitation as no clear guidelines are indicating where poor employment ends and trafficking begins (De Jonge van Ellemeet 2007). Nevertheless, Dutch courts have played a prominent role in further defining guidelines (Esser and Dettmeijer-Vermeulen 2016). From a legal point of view, it does not matter whether one self-identifies with victimhood or not. In 2009 the Supreme Court of the Netherlands ruled that Dutch standards are decisive, regardless of the experiences of the standards of those involved (Supreme Court, HR 27 October 2009, LJN BI7097; BI7099 and NJ 2010/598; Rijken et al. 2013). However, like in many other parts of the world, detection and prosecution of labor trafficking are frustrated by a low degree of self-identification. Martens and Van den Brink (2013) observe that in the Dutch criminal investigation practice, it is difficult to get victims to report their victimhood and to testify against their traffickers because they often do not self-identify with their victimhood.

\section{Two Trajectories to Self-Identification in the Netherlands}

In this section, the findings of a study are discussed which explores the ideal-typical trajectories through which actors $d o$ self-identify with their victimhood (Tielbaard et al. 2016). This study drew on semi-structured interviews and focus groups with victims of labor trafficking and focus groups with professionals who work in the field. All participants in the study identified with their victimhood of labor trafficking as this was used as a selection criterion. It was indicated that although most of the study's participants did not struggle with the label "victim," some felt uncomfortable 
with the word "victim" as it made them feel powerless. Moreover, it was argued that even though all of the study's participants self-identified with their victimhood, the way they dealt with their victim role differed.

The study's findings indicate that people who had been recruited by a human trafficker in their country of origin feel more victimized than people who had arranged their trip themselves. The latter group regarded the exploitation merely as a form of incidental lousy luck. They perceived themselves as victims, but their victimization was linked to that one event only. Victimization had not become their master status, as is often the case with victims who have been recruited. The explanation for this difference in how grave the victimization is perceived that the authors of the study provide is that the first group felt like they were intentionally harmed by an organization that was out to exploit them from the start. The second group, on the other hand, related the "bad luck" to an individual employer and not so much to an organization. In other words, in the first group, victims may have perceived themselves as targets of organized crime, whereas, in the second group, people felt victimized by an individual, and, according to the authors, this explains why they experience their victimhood differently.

Also, it was noted that the experiences of victimhood of labor trafficking varied according to their countries of origin. When compared with victims from South America, Asian victims reported their victimhood less quickly, were less likely to seek help, and less inclined to tell their relatives about the exploitation. Cultural views on victimization were found to be closely linked to views on gender roles as well. Tielbaard et al. (2016) suggest that gender probably played a role in the way victims openly discuss their victimization. Some participants in the study asserted that the idea that "real" men are not victims of exploitation was ubiquitous and that social pressure was often exerted on men to "not overreact." Consequently, men were ashamed of their victimhood and less eager to express it than the female victims did.

The article discusses two ideal-type trajectories through which participants arrived at self-identification as victims of labor trafficking. The first involved a gradual increase in the victim's awareness. At first, the working conditions were perceived as bearable. However, as victims received more information about their rights and the prevailing norms and values of the Dutch labor market and as the working conditions deteriorated, they gradually became more aware of the exploitative situation in which they found themselves. As a result, they no longer accepted the situation and sought help or left the workplace. What the authors strike as remarkable in this trajectory was that the process of self-identification, and reporting it or seeking help, did not necessarily take place simultaneously. They conclude that self-identification probably acted as a necessary precondition for being able to leave the trafficking situation. In some instances, victims indeed did leave. Sometimes, however, victims returned to confront their exploiters and subsequently gained full realization of their victimhood. The authors hence conclude that self-identification of victimhood and seeking justice, compensation, or reaching out for help is not necessarily the same thing. Although these processes may be linked, they probably carry clear obstructions as well as distinct mechanisms that trigger them. 
The authors report that victims in the second trajectory had consistently worked under deplorable conditions. They did not see any alternatives and therefore felt they had no choice but to accept their situation as it was. Victims only became aware of their victimhood after a radical, far-reaching event in the (personal) life of the victim. This original event seemed to serve as a wake-up call for the victim. Examples of radical events that the authors mention are forced marriage, illness, or a death threat. In these moments, the victims realized that they could no longer accept the situation. In this process, the moment of self-identification did coincide with the moment when they started to look for help or with the instant left the work situation. Hence, in this trajectory self-identifying and taking action to leave the situation took place more or less simultaneously. It is, of course, possible that victims in this trajectory already felt that their employer treated them badly or even experienced that they were being exploited, but that this feeling had been suppressed unconsciously until the original event took place so that in their memory the self-identification and subsequent action coincided.

The authors argue that information gathering seemed to have played a smaller role in this trajectory than in the first. It was not the attainment of new information or legal knowledge but the original event that triggered their self-identification as a victim. Nevertheless, they indicate that it may be argued that in some instances the information received allowed some victims to know where they could turn to get help. Therefore, it is concluded that, although the provision of information only played a role in the first trajectory as a "trigger" for self-identification, in the second trajectory, it served as a precondition for being able to leave the exploitative situation.

The way that victims process information may further be influenced by their level of education. Tielbaard et al. (2016) suggest that victims with a higher level of education may process this information more efficiently, can make their conclusions, and then act accordingly. For less educated victims, the processing of information is suggested to be more difficult. For those with a lower level of education, the information does play a role after they have come to self-identification via a radical event (trajectory 2 ) or in combination with worsening working conditions (trajectory 1).

\section{Discussion}

Labor trafficking is an offence that does not take place at one moment in time but has a long-term character that can change in how it manifests itself along the way. There is no clear-cut victimization moment, as there is with robbery or assault. Moreover, the exploitative processes are often embedded in a relationship and in social interactions that are dynamic. This means that victimization of labor exploitation cannot easily be compared with the victimization of other crimes. Self-identification of victimhood can take place at various moments during or after the exploitative situation(s), or not at all. Self-identification may be crucial for the potential victim in order to try to leave the situation or seek (formal) help. All the more so because 
research shows that the victims identified by investigative services only make up a small fraction of the actual number of victims of labor exploitation (Goodey 2008; Zhang 2012). Self-Identification is not the only avenue out of the exploitative situation, as potential victims may also be able to leave a labor situation they regard exploitative without also perceiving this as labor trafficking.

That labor trafficking should be considered along the lines of a continuum (Skrivankova 2010) is underlined by the findings of the study by Tielbaard et al. (2016) on how victims do arrive at self-identification. In this study, two trajectories are identified through which victims of labor exploitation arrive at self-identification. On the first path, the victim gradually comes to self-identification. This happens because the working conditions gradually deteriorate or because the victim receives more information about her/his rights as an (undocumented) employee on the Dutch labor market. Victims can also follow the second trajectory, in which a radical event in their personal lives causes them to become aware of their victimhood. In line with previous research, information provision emerges as a factor that can contribute to self-identification (trajectory 1) or as a precondition for being able to leave the situation and seek help (trajectory 2). Information about the rights of employees on the Dutch labor market can speed up or confirm the self-identification process for the victims in the first trajectory. In the second trajectory, information provision is not a "trigger" of self-identification, but it plays a role in finding support agencies after self-identification.

Future research would do well to systematically analyze why the gathering of information in itself is sufficient for some victims to come to self-identification, whereas for other victims a particular event is needed - and what role the level of education plays in this. The educational level could, for instance, play a role in the way actors perceive workplace rights and aspirations for a better future. Previous sociological research has shown that the appreciation of rights by migrants is among others dependent on educational level and class before their migration (e.g., Wong 2011). These are all possible avenues for further research.

The current body of knowledge discussed here provides support for the value of initiatives aimed at promoting information and awareness among vulnerable populations. Governments and NGOs play an essential role in providing relevant information to those engaged in precarious forms of employment or migration pathways. The research we have considered, moreover, demonstrates that it is essential to distinguish between the provision of information that can lead to selfidentification as a victim and information that can lead to seeking help or reporting. For some victims, the barriers will remain too high to go to the police or an organization, while they might try to leave their exploitative situation, or struggle to improve it, if only they could identify with their victimhood. Providing information through the proactive efforts of people with the same national or cultural background as potential victims can lower the threshold to report their victimhood to the authorities. There may also be a role for authorities such as police or emergency services, to provide information about labor rights or rights for irregular migrants, for example, during regular inspections. 
Furthermore, as discussed, it is crucial to make a clear distinction between selfidentification and taking action by this self-identification, i.e., seeking help or reporting to the police. Tielbaard et al. (2016) have argued that with the occurrence of a significant event (trajectory 2), self-identification may coincide with turning to the authorities, but this was not always the case with gradual awareness (trajectory 1). Sometimes self-identification occurred, but no action was taken. Self-identification is probably a necessary condition but comes about differently and has other obstacles than any follow-up action has. This lack of taking action after selfidentification supports the observations of the literature review. For instance, the moral economy approach (Scott 1976; Hiah and Staring 2016) explains why for some workers, specific labor conditions that the legal context would frame as exploitative are morally acceptable because they are justified by ethnic, hierarchical, religious, or political differences or from interdependencies and vulnerabilities. Besides, migration background and mindset can play a role in explaining why actors can temporarily accept labor injustice because they perceive this as an avenue to upward social mobility or more simply that the labor conditions in the country of the settlement are better than in the country of origin. The importance of the migration background resonates with the findings of Tielbaard et al. (2016). They find that having an undocumented status, for example, acted as a barrier to approaching the police, but not to self-identification of victimhood. These insights draw up questions regarding the underlying mechanisms of migration and the redistribution of wealth and well-being. Alternatively, Anderson and Andrijasevic critically reflect: when people are being exploited in other countries, we call that poverty, but when they are exploited right before our nose, we call that trafficking (Anderson and Andrijasevic 2008: 138-142).

All in all, the two trajectories identified by Tielbaard et al. (2016) suggest that self-identification of labor trafficking victimization takes place in a complex context in which various sociocultural aspects play a role and in which the word victim carries significant symbolic power, which victims themselves often struggle with (see, e.g., Best 1999). Moreover, the scholarly literature discussed here underlines that to understand the low rate of self-identification of labor trafficking victimization, labor trafficking is probably best approached as something that is experienced by an actor and not so much as something that happens to one. For professionals, it is crucial to realize that there are clear obstructions to self-identification on the one hand and to cooperate with authorities or organizations on the other hand.

Finally, Best (1999) argues that identifying and labeling victims also have a symbolic social function. Improving the self-identification of victims answers the social need for justice. The aim is not only to provide potential victims with the right tools for self-identification but also to help them find alternative solutions to the official recognition as victims of labor trafficking. Solutions that aim for social justice but do not necessarily involve criminal justice. In other words, improving labor conditions, awareness of rights, and empowering people who engage in precarious work, without workers ending their labor situation by starting a criminal procedure (e.g. Hiah forthcoming; Shamir 2012). As ample research has shown, an emphasis on the dichotomy of victim and perpetrator does not always do justice to 
the social realities of labor exploitation (Hiah and Staring 2016; Parreñas 2011). Solutions that take this diversity in social realities into account will not only benefit those who are potential victims but may improve labor conditions for all vulnerable groups in the labor market.

\section{Summary}

With the criminalization of labor exploitation as human trafficking, more and more cases of labor trafficking come to light. However, many cases also remain undetected (i.e., "dark figure" of crime). This under-identification is, in part, due to the low levels of self-identification of victimization of labor trafficking. Low self-identification suggests that a discrepancy exists between legal definitions of labor trafficking victimhood and the lived experiences of work and employment by what are often labor migrants. For the future combat of labor trafficking, it is of vital importance to better understand the reasons for this low-self-identification. This contribution discusses scholarly literature that identifies factors that obstruct self-identification among those subjected to labor exploitation.

On the one hand, as with all forms of crime, low rates of self-identification can be a consequence of victims' narrow definitions of victimization or because of psychological mechanisms such as denial or repression. On the other hand, some factors are specifically associated with what legally is defined as labor trafficking. Labor trafficking often refers to situations in which migrants have consciously left their country of origin in search of work. Their work conditions may be valued as a temporary arrangement to achieve socioeconomic mobility upward and considered from their home country's work and income standards. Therefore, such migrants may perceive themselves as active agents of their destiny who make their own decisions in engaging in certain working conditions and not as passive victims of exploitation. The third set of explanations for the lack of self-identification emphasizes that exploitation takes place within the setting that involves power relationships governed by a "moral economy" that legitimizes those imbalances based on ethnic, hierarchical, religious, or political differences or on the basis of perceived vulnerabilities. In other words, exploitation may be legitimized or accepted and hence not recognized as exploitation by those involved. Two trajectories are discussed through which victims of labor exploitation do arrive at self-identification. On the first path, the victim gradually comes to self-identification. This happens because the working conditions gradually deteriorate or because the victim receives more information about her/his rights as an (undocumented) employee on the Dutch labor market. Victims can also follow the second trajectory, in which a radical event in their personal lives triggers them to become aware of their victimhood. Overall, it is suggested that self-identification of labor trafficking victimization takes place in a complex context in which various sociocultural aspects play a role and in which the word victim carries significant symbolic power. 


\section{Cross-References}

(anti)Trafficking for Labor Exploitation in Romania: A Labor Perspective

- A Transnational Field Approach to the Study of Labor Trafficking

- Exploitation of Migrant Workers: A Multi-Legal Approach of Labor Exploitation

- Human Trafficking in Supply Chains and the Way Forward

- National Rapporteur on Trafficking in Human Beings and Sexual Violence Against Children, The Netherlands

- Victim Protection and Reintegration

\section{References}

Anderson, B. \& Andrijasevic, R. (2008). Sex, slaves and citizens: the politics of anti-trafficking. Soundings, 40, 135-145

Barrick, K., Lattimore, P., Pitts, W., \& Zhang, S.X. (2014). When farmworkers and advocates see trafficking, but law enforcement does not: challenges in identifying labor trafficking in North Carolina. Crime, Law and Social Change, 66(2), 205-214.

Bélanger, D. (2014) Labor migration and trafficking among Vietnamese migrants in Asia. The ANNALS of the American Academy of Political and Social Science, 653(1): 87-106

Best, J. (1999) Random violence. How we talk about new crimes and new victims. Berkeley: University of California Press

Bloch, A. \& McKay, S. (2013). Hidden dishes - how food gets on to our plates: Undocumented migrants and the restaurant sector. Journal of Workplace Rights, 17(1): 69-91.

Cockbain, E., Bowers, K., \& Dimitrova, G. (2018) Human trafficking for labor exploitation: the results of a two-phase systematic review mapping the European evidence base and synthesizing key scientific research evidence. Journal of Experimental Criminology, https://doi.org/10.1007/ s11292-017-9321-3

Datta, M. \& Bales, K. (2013). Slavery in Europe: Part 1, estimating the dark figure. HumanRights Quarterly, 35(4). 817-829.

De Jonge van Ellemeet, H. (2007). Slecht werkgeverschap of 'moderne slavernij'; handhaving van een nader af te bakenen verbod. Justitiële verkenningen, 33(7), 107-119.

Dutch National Rapporteur (2009). Mensenhandel - Zevende rapportage van de Nationaal rapporteur. Den Haag: BNRM.

Esser, L. B. \& Dettmeijer-Vermeulen, C. E. (2016). The Prominent Role of National Judges in Interpreting the International Definition of Human Trafficking. Anti-Trafficking Review, (6), 91.

Goodey, J. (2008). Human trafficking: Sketchy data and policy responses. Criminology \& Criminal Justice, 8(4), 421-442.

Hiah, J., (forthcoming). Between employment and exploitation. The impact of criminalization of labour exploitation as human trafficking on labour relations in Chinese migrant businesses in the Netherlands and Romania. Ph.D. dissertation. Erasmus University Rotterdam, Rotterdam

Hiah, J. \& Staring, R. (2-13). 'Maar Hollanders zouden zeggen dat het uitbuiting is...' Chinese restauranthouders en illegale Chinezen over werken bij 'de Chinees', Tijdschrift voor Criminologie, 55(1): 44-58

Hiah, J. \& Staring, R. (2016). 'But the Dutch would call it exploitation.' Crimmigration and the moral economy of the Chinese catering industry in the Netherlands. Crime, Law and Social Change, 66(1), 83-100.

Jacoby, T. A. (2015). A theory of victimhood: Politics, conflict and the construction of victim-based identity. Millennium, 43(2), 511-530.

Jägers, N. \& C. Rijken (2014) Prevention of human trafficking for labor exploitation. The role of corporations. Northwestern Journal of Human Rights, 12(1): 1-28 
Joarder, M.A.M. \& P.W. Miller (2014) The experiences of migrants trafficked from Bangladesh. The ANNALS of the American Academy of Political and Social Science, 653(1):141-161

Kaye, J., Winterdyk, J. \& L. Quarterman (2014) Beyond criminal justice. A case study of responding to human trafficking in Canada. Canadian Journal of Criminology and Criminal Justice, 56(1):23-48.

Leun, J.P. van der \& Schijndel, A. van. (2012). Uitbuiting uit zicht? Getuigenverklaringen van gesmokkelde migranten nader bekeken aan de hand van indicatoren voor mensenhandel. Tijdschrift voor Veiligheid, 11(3), 20-37.

Leun, J.P. van der. \& van Schijndel, A. (2016). Emerging from the shadows or pushed into the dark? The relation between the combat against trafficking in human beings and migration control. International Journal of Law, Crime and Justice, 44, 26-42.

Marmo, M. \& Chazal, N. (2016) Transnational Crime \& Criminal Justice. Sage, London

Martens, E.D.I. \& Brink, S.E. van den. (2013). Van signaal tot tenlastelegging? Uitdagingen in de opsporing, vervolging en berechting van mensenhandel. Strafblad, 11(3). 195-204.

Meeteren, M. van (2014) Irregular migrants in Belgium and the Netherlands. Aspirations and incorporation. Amsterdam University Press, Amsterdam

Parreñas, R. S. (2011). The indentured mobility of migrant women: How gendered protectionist laws lead Filipina hostesses to forced sexual labor. Journal of Workplace Rights, 15(3), 327-344.

Petrunov, G. (2014). Human Trafficking in Eastern Europe: The case of Bulgaria. The Annals of the American Academy of Political and Social Science, 653(1), 162-182.

Postma, D. \& Wijk, J. van. (2012) Op het land in plaats van achter het raam. Aard en omvang van arbeidsuitbuiting in Nederland. Proces, 91(5), 327-339.

Rijken, C., Dijk, J. van., \& Klerx-van Mierlo, F. (2013). Mensenhandel: het slachtofferperspectief. Een verkennende studie naar behoeften en belangen van slachtoffers mensenhandel in Nederland. Tilburg: International Victimology InstituteTilburg (INTERVICT).

Scott, J. C. (1976). The moral economy of the peasant. New Haven: Yale University Press.

Shamir, H. (2012). A Labor Paradigm for Human Trafficking. UCLA Law Rev 60:76-136.

Skrivankova, K. (2010). Between decent work and forced labor: examining the continuum of exploitation. York: Joseph Rowntree Foundation.

Staring, R.H.J.M. (2012). Moderne slavernij of gewoon werk? Den Haag: BJu.

Strauss, K. \& McGrath, S. (2017). Temporary migration, precarious employment and unfree labour relations: Exploring the 'continuum of exploitation' in Canada's Temporary Foreign Worker Program. Geoforum, 78, 199-208.

Supreme Court, HR 27 October 2009, LJN BI7097; BI7099 and NJ 2010/598.

Tielbaard N., Meeteren M.J. van, \& Commandeur X. (2016), Slachtoffer van arbeidsuitbuiting? Een kwalitatieve studie naar ideaaltypische trajecten die leiden tot zelfidentificatie als slachtoffer van mensenhandel, Tijdschrift voor Criminologie 58(2): 37-54.

Turner-Moss, E., Zimmerman, C. Howard, L.M., \& Oram, S. (2014). Labor exploitation and Health: A Case Series of Men and Women Seeking Post-Trafficking Services. Journal of Immigrant and Minority Health, 16(3), 473-480.

UNODC and the Dutch National Rapporteur (2017) Monitoring Target 16.2 of the United Nations Sustainable Development Goals A multiple systems estimation of the numbers of presumed human trafficking victims in the Netherlands in 2010-2015 by year, age, gender, form of exploitation and nationality. Research Brief. UNODC and the Dutch National Rapporteur.

Van Meeteren, M. (2016) Are you a victim? The low self-identification of victims of labour exploitation. Leiden Law Blog. Available at https://eidenlawblog.nl/articles/are-you-a-victimthe-low-self-identification-of-victims-of-labour-exploitat

Vijeyarasa, R. (2012). The Cinderella syndrome: Economic expectations, false hopes and the exploitation of trafficked Ukrainian women. Women's Studies International Forum, 35 (1), $53-62$.

Weitzer, R. (2014). New Directions in Research on Human Trafficking. The Annals of the American Academy of Political and Social Science, 653(6), 6-24. 
Wong, L. (2011). Chinese migrant workers: rights attainment deficits, rights consciousness and personal strategies. The China Quarterly, 208,.870-892.

Yea, S. (2012). 'Shades of grey': spaces in and beyond trafficking for Thai Women involved in commercial sexual labour in Sydney and Singapore. Gender, Place \& Culture, 19(1), 42-60.

Zhang, S. (2012). Measuring labor trafficking: a research note. Crime Law and Social Change, 58(4), 469-482. 